\title{
Spunbonded Fabric Covers Suggest Possibilities to Alter Early Season Growth and Fruiting in Cranberry
}

\author{
Elden J. Stang', John Klueh ${ }^{2}$, and Brian A. Birrenkott ${ }^{3}$ \\ Department of Horticulture, University of Wisconsin, Madison, WI 53706
}

Additional index words. Vaccinium macrocarpon, rowcovers

Use of spunbonded fabrics as covers to alter plant development, modify microclimate, provide protection from insects and animals, and improve productivity, as highlighted by Wells and Loy (1985), is now commonplace for a host of high-value horticultural crops. In strawberry, rowcovers are reported to provide enhanced accumulation of heat units, limited protection from frost, earlier flowering, increased plant growth, and potential for increased yield (Gast and Pollard, 1988; Pollard and Cundari, 1988).

Evaluation of spunbonded fabric covers on cranberry plant development and fruiting has not been reported and was the objective of this preliminary research. Recent research on fruit set in cranberry indicates high levels of soluble carbohydrates in cranberry shoot upright growth at early blossom stages are important in determining subsequent fruit set (Birrenkott, 1989). Onset of earlier seasonal growth as a result of covers, if concurrent with enhanced photosynthesis and higher carbohydrate levels, might offer potential for increased fruit set and productivity.

Typar spunbonded polypropylene fabric (Reemay, Hickory, Term.) was placed over a mature, producing 'Searles' cranberry planting in north-central Wisconsin on 5 Dec. 1988. Typar is a heavy-duty fabric with ultraviolet stabilizers added for resistance to degradation by sunlight. Weight of the sheet is $70.6 \mathrm{~g} \cdot \mathrm{m}^{-2}$, with substantial resist ante to puncturing or tearing and potential for reuse.

A total area of $2100 \mathrm{~m}^{2}$ was covered using four large sheets of Typar. Uncovered con-

Received for publication 16 Nov. 1989. Research supported in part by the College of Agricultural and Life Sciences, Univ. of Wisconsin-Madison. We thank R.S. Brazeau, Inc., Wisconsin Rapids, Wis., for use of plantings and R.S. Brazeau and Reemay, Inc., Old Hickory, Term., for providing the spunbonded covers used in this research. The cost of publishing this paper was defrayed in part by the payment of page charges. Under postal regulations, thispaperthereforemustbeherebymarked advertisement solely to indicate this fact.

'Professor.

${ }^{2}$ Assistant Researcher

${ }^{3}$ Former Graduate Research Assistant. trol areas were located adjacent to covered plots in the same cranberry bed. Fabric covers were held in place with 9-mm-diameter steel concrete-reinforcing rods laid along the fabric edges, pinned down with heavy-gauge wire hooks inserted into the soil. Remote thermocouples were tied to stakes at plant height $(\approx 10 \mathrm{~cm})$ under the covers and in control areas for temperature monitoring. Soil temperatures were measured using a Taylor dial probe thermometer inserted to $15-\mathrm{cm}$ depth through the fabric covers.

The bed was flooded for winter protection by 10 Dec. 1988 and a 25 -cm-thick ice layer was frozen over control and covered areas. Ice remained throughout Winter 1988-89 until melting and drainage in early April. Individual Typar covers, $\approx 500 \mathrm{~m}^{2}$ each, were removed at intervals of $\approx 3$ weeks, beginning 17 Apr.

The plantings were observed at intervals during the growing season to determine effects of covers on growth and fruiting. Six random samples of $\approx 50$ upright shoots and four samples of fruit $(\approx 300 \mathrm{~g}$ each) were taken from each plot on 29 Sept. 1989 for determination of percent fruit set, fruit weight, yield, and anthocyanin content of fruit.

During the cool early spring, canopy air temperatures under spunbonded fabric were 5 to $6 \mathrm{C}$ higher than in exposed control plants. Differences ranged as great as $17 \mathrm{C}$, with a maximum temperature of $45 \mathrm{C}$ measured under covers with full sunshine in late May and early June. Temperatures suitable for initiation of active metabolism, estimated to be at 6 to $7 \mathrm{C}$, resulted in earlier greening of leaf tissue under fabric covers. Nevertheless, differences in recognizable stages of current season's growth and flower development were negligible. Despite earlier greening, lack of visible earlier elongation may in part be related to a negligible effect of the covers on soil temperature (Table 1). The cranberry plant canopy appears to provide an insulating effect on soil temperature at least during early spring. However, soil temperature began to increase substantially by late May.

Although no significant differences existed, a trend to increased fruit set was apparent when plant covers remained in place until late May and early June (Table 1). This trend also was noted in samples taken solely for fruit set determination in early September (data not shown). However, no clear trend for increased yield was evident in samples taken at normal harvest. Anthocyanin content of fruit at harvest varied, but did not appear to be related to the time of cover removal.

Current evidence for the positive influence of soluble carbohydrates at early blossom on fruit set in cranberry (Birrenkott, 1989) suggests that earlier leaf greening, if concomitant with enhanced soluble carbohydrate production, could enhance subsequent fruit set. Evidence in this study is not adequate to warrant a conclusion that spunbonded fabric covers either provided earlier enhanced carbohydrate levels or enhanced fruit set.

\section{Literature Cited}

Birrenkott, B.A. 1989. Determining the causes of low fruit set in cranberry. PhD Diss. Univ. of Wisconsin, Madison.

Gast, K.L.B. and J.E. Pollard. 1988. Overwintering strawberry plants under rowcovers: effects on development of yield components. HortScience 23:776 (Abstr.)

Pollard, J.E. and C.M. Cundari. 1988. Overwintering strawberry plants under rowcovers increases fruit production. HortScienee $23: 332$ 333.

Wells, O.S. and J.B. Loy. 1985. Row covers: a changing landscape. HortScience 20:800.

Table 1. Soil temperature and fruit characteristics in 'Searles' cranberry as influenced by date of removal of Typar polypropylene fabric cover.

\begin{tabular}{|c|c|c|c|c|c|c|}
\hline \multirow{2}{*}{$\begin{array}{l}\text { Date of } \\
\text { cover } \\
\text { removal }\end{array}$} & \multicolumn{3}{|c|}{ Soil temp $\left({ }^{\circ} \mathrm{C}\right)$} & \multirow{2}{*}{$\begin{array}{c}\text { Fruit } \\
\text { set }(\%)\end{array}$} & \multirow{2}{*}{$\begin{array}{c}\text { Yield } \\
\left(\mathrm{g} / 81 \mathrm{~cm}^{2}\right)\end{array}$} & \multirow{2}{*}{$\begin{array}{l}\text { Anthocyanin } \\
(\mathrm{mg} / 100 \mathrm{~g})\end{array}$} \\
\hline & 2 May & 23 May & 6 June & & & \\
\hline $\begin{array}{l}17 \text { Apr. } \\
2 \text { May } \\
23 \text { May } \\
6 \text { June } \\
\text { No cover }\end{array}$ & $\begin{array}{l}2.3 \\
1.3 \\
1.7 \\
3.3 \\
2.5\end{array}$ & $\begin{array}{l}12.4 \\
12.5 \\
12.5 \\
13.7 \\
11.4\end{array}$ & $\begin{array}{l}15.3 \\
14.2 \\
15.1 \\
17.6 \\
14.0\end{array}$ & $\begin{array}{l}35.8 \\
34.4 \\
42.0 \\
42.6 \\
39.6\end{array}$ & $\begin{array}{l}37.8 \\
31.7 \\
43.2 \\
37.2 \\
41.4\end{array}$ & $\begin{array}{l}20.5 \mathrm{c} \\
17.5 \mathrm{a} \\
19.3 \mathrm{~b} \\
21.5 \mathrm{c} \\
21.0 \mathrm{c}\end{array}$ \\
\hline No cover & & & & NS & NS & \\
\hline
\end{tabular}

${ }^{\mathrm{z}}$ Adjusted yield using number of flowering uprights as a covariate.

'Mean separation at $\mathbf{P}=0.05$, Fisher's protected LSD; NS, nonsignificant. 